\title{
Massilia dura sp. nov., Massilia albidiflava sp. nov., Massilia plicata sp. nov. and Massilia lutea sp. nov., isolated from soils in China
}

\author{
Correspondence \\ Wen-Jun Li \\ wjli@ynu.edu.cn \\ Ren Lai \\ rlai72@njau.edu.cn
}

\author{
Yu-Qin Zhang, ${ }^{1,2,3} \dagger$ Wen-Jun $\mathrm{Li}^{2}{ }^{\dagger} \dagger \mathrm{Ke}-\mathrm{Yun}$ Zhang, ${ }^{1}$ Xin-Peng Tian, ${ }^{2}$ \\ Yi Jiang, ${ }^{2}$ Li-Hua $\mathrm{Xu}^{2}{ }^{2}$ Cheng-Lin Jiang ${ }^{2}$ and Ren Lai ${ }^{1}$ \\ ${ }^{1}$ Key Laboratory of Microbiological Engineering of Agricultural Environment, Ministry of \\ Agriculture, School of Biological Sciences, Nanjing Agriculture University, Nanjing, Jiangsu \\ 210095, People's Republic of China \\ ${ }^{2}$ Key Laboratory for Microbial Resources of Ministry of Education, Yunnan Institute of \\ Microbiology and Laboratory for Conservation and Utilization of Bio-Resources, Yunnan \\ University, Kunming, Yunnan 650091, People's Republic of China \\ ${ }^{3}$ Institute of Medicinal Biotechnology, Chinese Academy of Medical Sciences and Peking \\ Union Medical College, Beijing 100050, People's Republic of China
}

\begin{abstract}
Four Gram-negative, motile, rod-shaped bacterial strains were isolated from soil samples collected from south-east China. A taxonomic study including phylogenetic analysis based on 16S rRNA gene sequences and phenotypic characteristics was performed. DNA $G+C$ contents of the four strains were 63-66 mol\%. Their predominant ubiquinone was Q-8. The fatty acid profiles contained $\mathrm{C}_{16: 1} \omega 7 c(36 \cdot 9-54 \cdot 7 \%)$ and $\mathrm{C}_{16: 0}(22 \cdot 8-25 \cdot 5 \%)$ as the major components. Based on their phenotypic characteristics, phylogenetic position as determined by $16 \mathrm{~S}$ rRNA gene sequence analysis and DNA-DNA hybridization results, the four isolates are considered to represent four novel species of the genus Massilia, for which the names Massilia dura sp. nov. (type strain $16^{\top}=$ CCTCC AB $204070^{\top}=$ KCTC $12342^{\top}$ ), Massilia albidiflava sp. nov. (type strain $45^{\top}=$ CCTCC AB $204071^{\top}=$ KCTC $12343^{\top}$ ), Massilia plicata sp. nov. (type strain $76^{\top}=$ CCTCC AB $204072^{\top}=$ KCTC $12344^{\top}$ ) and Massilia lutea sp. nov. (type strain $101^{\top}=\mathrm{CCTCC} \mathrm{AB}$ $204073^{\top}=$ KCTC $12345^{\top}$ ) are proposed.
\end{abstract}

The genus Massilia was first described by La Scola (1998) based on a single isolate from the blood of an immunocompromised patient with meningoencephalitis. Subsequently, the use of $16 \mathrm{~S}$ rRNA gene sequence analysis led to the identification of a second isolate of Massilia timonae from a surgical wound infection in an immunocompetent 36-year-old male who had undergone orthopaedic surgery (Sintchenko et al., 2000). More recently, Lindquist et al. (2003) presented taxonomic results for another four Massilia-like isolates (85A2206, 96A14209, 97A4424 and 99A9205) from different patients, including 16S rRNA gene sequence analysis, conventional biochemical test results,

Published online ahead of print on 11 November 2005 as DOI 10.1099/ijs.0.64083-0.

tThese authors contributed equally to this work.

The GenBank/EMBL/DDBJ accession numbers for the 16S rRNA gene sequences of strains $16^{\top}, 45^{\top}, 76^{\top}$ and $101^{\top}$ are AY965998, AY965999, AY966000 and AY966001, respectively.

Tables detailing the cellular fatty acid profiles and levels of DNA-DNA relatedness among the four novel strains are available as supplementary material in IJSEM Online. morphological and flagellar characteristics and cellular fatty acid analysis. They provided an emended description of M. timonae as follows: 'Cells are Gram-negative medium straight rods. They are motile, predominantly by means of a single polar flagellum, lateral flagella may also occur. Tests for oxidase and catalase are positive.'

The present investigation was designed to establish the taxonomic position of four novel Massilia-like isolates, which formed a distinct clade with species of the genera Massilia and Telluria within the family Oxalobacteraceae. Genotypic and phenotypic data indicate that these strains should be recognized as representing four novel species of the genus Massilia.

Four strains designated $16^{\mathrm{T}}, 45^{\mathrm{T}}, 76^{\mathrm{T}}$ and $101^{\mathrm{T}}$ were isolated by using the dilution plating method from soil samples polluted with heavy metals from a farm situated in a suburb of Nanjing, Jiangsu Province, south-east China. The medium used for isolation was yeast extract/malt extract agar $(4 \cdot 0 \%$ yeast extract, $10 \cdot 0 \%$ malt extract, $4 \cdot 0 \%$ glucose, $2 \cdot 0 \%$ agar) (ISP 2 medium; Shirling \& Gottlieb, 1966); incubation was at $28{ }^{\circ} \mathrm{C}$ for 2 weeks. Biomass for molecular systematic and 


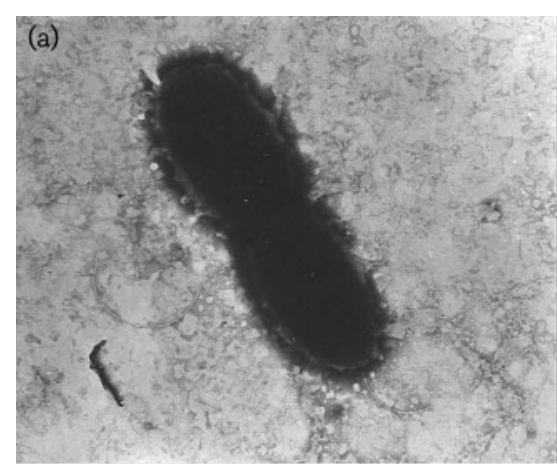

(c)

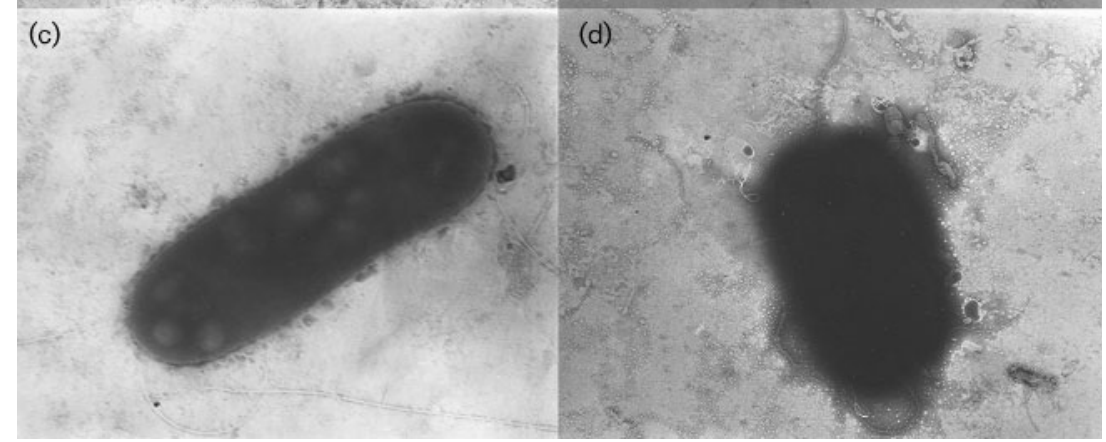

(b)

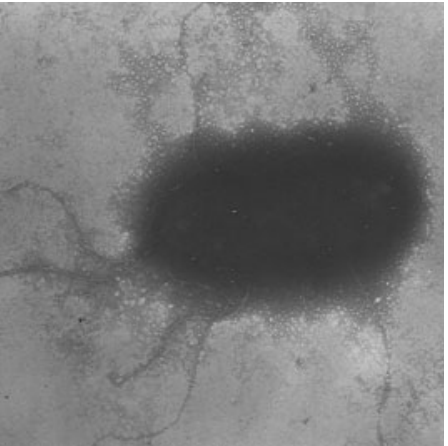

(d)
Fig. 1. Transmission electron micrographs of cells of strains $16^{\top}$ (a), $45^{\top}$ (b), $76^{\top}$ (c) and $101^{\top}$ (d) after $24 \mathrm{~h}$ growth on ISP 2 agar medium. Original magnification, $\times 20000$ (a), $\times 12000(b, d)$ and $\times 30000(c)$. chemotaxonomic studies was obtained after incubation at $28^{\circ} \mathrm{C}$ for 3 days in shake flasks of tryptone soy broth (TSB; Oxoid). Cellular morphological characteristics of the four new isolates were observed by light microscopy (model BH 2; Olympus) and by transmission electron microscopy (model H-800; Hitachi) after 24 h growth on ISP 2 medium. For transmission electron microscopy observation, cells were negatively stained with $1 \%(\mathrm{w} / \mathrm{v})$ phosphotungstic acid after air drying. Motility of cells was studied on LB swarming agar $(0.3 \%, \mathrm{w} / \mathrm{v})$, and observation of flagella was performed using the method of Leifson (1960). Colony morphology was determined after 3 days growth at $28^{\circ} \mathrm{C}$ on ISP 2 agar. Colour determination was made with colour chips from the ISCC-NBS Color Charts (Kelly, 1964).

Growth was tested at $4,10,28,37,40,45$ and $55^{\circ} \mathrm{C}$ on ISP 2 medium. $\mathrm{pH}$ and $\mathrm{NaCl}$ tolerance experiments were performed as described by Xu et al. (2005). Other physiological and biochemical tests were carried out as described by $\mathrm{Li}$ et al. (2004).

Colonies of the four isolates shared several features such as whitish yellow to yellow colours, convex shape and plicate form on ISP 2 agar. Colonies of strains $76^{\mathrm{T}}$ and $101^{\mathrm{T}}$ reached a maximum of $2 \cdot 0-3 \cdot 0 \mathrm{~mm}$ in diameter after 3 days incubation at $28^{\circ} \mathrm{C}$, while those of strains $16^{\mathrm{T}}$ and $45^{\mathrm{T}}$ were about $1 \cdot 0-1 \cdot 5 \mathrm{~mm}$ in diameter. Cells of all four strains were Gramnegative, motile, non-spore-forming rods with one or more flagella, about $0 \cdot 6-2 \cdot 0 \mu \mathrm{m}$ in width and $2 \cdot 0-3 \cdot 5 \mu \mathrm{m}$ in length (Fig. 1). Detailed phenotypic characteristics and their variation among the four strains and reference strain $M$. timonae $\mathrm{CIP} 105350^{\mathrm{T}}$ are given in Table 1 and in the species descriptions.
Ubiquinones were isolated using the methods of Minnikin et al. (1984) and separated by HPLC (Kroppenstedt, 1982). The predominant ubiquinone for the four strains was Q-8. Cellular fatty acid compositions were determined as described by Sasser (1990) using the Microbial Identification System (MIDI, Inc.). The major cellular fatty acids were $\mathrm{C}_{16: 1} \omega 7 c(36 \cdot 9-54 \cdot 7 \%)$ and $\mathrm{C}_{16: 0}(22 \cdot 8-25 \cdot 5 \%)$; cellular fatty acid profiles for the four strains are given in Supplementary Table S1, which is available in IJSEM Online.

Extraction of genomic DNA and amplification of the $16 \mathrm{~S}$ rRNA gene were performed as described by Xu et al. (2003). Phylogenetic analysis was performed using the software packages PHYLIP (Felsenstein, 1993) and MEGA version 2.1 (Kumar et al., 2001) after multiple alignment of data by using CLUSTAL_X (Thompson et al., 1997). Distances (distance options according to the Kimura two-parameter model; Kimura, 1980, 1983) and clustering were based on the neighbour-joining (Saitou \& Nei, 1987) and maximumlikelihood (Felsenstein, 1981) methods. Bootstrap analysis was used to evaluate the tree topology of the neighbourjoining data by performing 1000 resamplings (Felsenstein, 1985). Genomic DNA for determination of the base composition was prepared following the method of Marmur (1961). DNA G + C contents were determined using the thermal denaturation method of Marmur \& Doty (1962). DNA-DNA hybridizations among the four isolates and their closest neighbour, M. timonae CIP $105350^{\mathrm{T}}$, were carried out applying the optical renaturation method (De Ley et al., 1970; Huß et al., 1983; Jahnke, 1992) under optimal hybridization conditions.

The almost complete 16S rRNA gene sequences for strains 
Table 1. Differential phenotypic characteristics among strains $16^{\top}, 45^{\top}, 76^{\top}$ and $101^{\top}$ and their nearest phylogenetic neighbour, M. timonae CIP $105350^{\top}$

Data for M. timonae CIP $105350^{\mathrm{T}}$ were taken from Lindquist et al. (2003). All strains show the following phenotypic characteristics. Cells are motile, non-spore-forming rods with flagella. Cellular fatty acids contain mainly $\mathrm{C}_{16: 1} \omega 7 c$ and $\mathrm{C}_{16: 0}$. Positive for catalase reaction and gelatin liquefaction, but negative for arginine dihydrolase, ornithine decarboxylase and indole production. Abbreviations: +, positive; -, negative; ND, no data.

\begin{tabular}{|lccccc|}
\hline Characteristic & $\mathbf{1 6}^{\mathbf{T}}$ & $\mathbf{4 5}^{\mathbf{T}}$ & $\mathbf{7 6}^{\mathbf{T}}$ & $\mathbf{1 0 1}^{\mathbf{T}}$ & M. timonae CIP $\mathbf{1 0 5 3 5 0}^{\mathbf{T}}$ \\
\hline Flagellation & Lateral & Lateral & Lateral & Lateral & Single or lateral \\
Nitrate reduction & + & + & + & - & - \\
Hydrolysis of starch & - & + & + & + & + \\
Enzyme activities: & & & & & - \\
$\quad$ Lysine decarboxylase & - & + & - & - & ND \\
$\quad \beta$-Glucuronidase & + & + & - & + & ND \\
$\quad N-$ Acetyl-glucosaminidase & + & + & - & + & ND \\
L-Aspartic arylamidase & - & + & + & + & ND \\
Lipase & - & + & + & + & + \\
Oxidase & + & + & - & + & - \\
$\quad$ Urease & + & + & + & - & ND \\
Methyl red test & + & - & - & - & $62-67$ \\
Voges-Proskauer test & - & - & + & - & Blood \\
DNA G+C content (mol\%) & $65 \cdot 9$ & $65 \cdot 3$ & $65 \cdot 1$ & $63 \cdot 3$ & \\
Isolation source & Soil & Soil & Soil & Soil & \\
\end{tabular}

$16^{\mathrm{T}}, 45^{\mathrm{T}}, 76^{\mathrm{T}}$ and $101^{\mathrm{T}}$ were determined as consisting of 1478, 1470, 1471 and $1478 \mathrm{bp}$, respectively. These 16S rRNA gene sequences (corresponding to Escherichia coli positions 46-518) showed $97 \cdot 1-99 \cdot 5 \%$ similarity with each other. However, they shared relatively low $16 \mathrm{~S}$ rRNA gene sequence similarity $(<95 \%)$ with all recognized genera of the family Oxalobacteraceae except with the genus Massilia (96.5\%). A neighbour-joining tree based on the 16S rRNA gene sequences of the four new isolates and related taxa is shown in Fig. 2. The four strains formed a distinct clade with the genus Massilia within the family Oxalobacteraceae.

According to the original description (La Scola et al., 1998) and subsequently emended description (Lindquist et al., 2003) of the genus Massilia, cells of the four novel strains have similar morphology to those of Massilia isolates: cells are non-spore-forming rods, motile by means of flagella. For all of these isolates, their major cellular fatty acids are $\mathrm{C}_{16: 1} \omega 7 c$ and $\mathrm{C}_{16: 0}$. They also share some other common phenotypic characteristics, as noted in Table 1. Phylogenetically, the four isolates were closest to M. timonae CIP $105350^{\mathrm{T}}$ (96.5\% 16S rRNA gene sequence similarity), and on this basis should be assigned to the genus Massilia.

Additionally, DNA-DNA hybridization among the four tested strains and the reference strain M. timonae CIP $105350^{\mathrm{T}}$ (see Supplementary Table S2 in IJSEM Online) gave results much lower than $70 \%$, the recommended threshold value for the delineation of genomic species (Wayne et al., 1987). This provided decisive evidence that the four isolates represent members of different genomic species. The $\mathrm{G}+\mathrm{C}$ contents of the genomic DNA from strains $16^{\mathrm{T}}, 45^{\mathrm{T}}, 76^{\mathrm{T}}$ and $101^{\mathrm{T}}$ were $65 \cdot 9,65 \cdot 3,65 \cdot 1$ and $63 \cdot 3 \mathrm{~mol} \%$, respectively.

Therefore, based on the phenotypic and genotypic data presented, we consider strains $16^{\mathrm{T}}, 45^{\mathrm{T}}, 76^{\mathrm{T}}$ and $101^{\mathrm{T}}$ to represent four novel species of the genus Massilia, Massilia dura sp. nov., Massilia albidiflava sp. nov., Massilia plicata sp. nov. and Massilia lutea sp. nov., respectively.

\section{Description of Massilia dura sp. nov.}

Massilia dura (du'ra. L. fem. adj. dura hard, referring to the nature of the colonies).

Colonies are $0.9-1.2 \mathrm{~mm}$ in diameter, circular, entire, convex, opaque, hard, compact and pale white to yellow on nutrient agar plates. Cells are $0 \cdot 6-0 \cdot 8 \mu \mathrm{m}$ in width and $1 \cdot 8-2 \cdot 2 \mu \mathrm{m}$ in length. Cells are motile, non-spore-forming, straight rods with one or more flagella, about $0 \cdot 7-0 \cdot 8 \mu \mathrm{m}$ in width and $2 \cdot 0-2 \cdot 5 \mu \mathrm{m}$ in length (Fig. 1a). Growth temperature and $\mathrm{pH}$ range for growth are $10-45^{\circ} \mathrm{C}$ and $\mathrm{pH} 6 \cdot 5-8 \cdot 5$, with optimum growth at $28-30^{\circ} \mathrm{C}$ and $\mathrm{pH} 7 \cdot 0-7 \cdot 5$. Cannot tolerate $>1 \% \mathrm{NaCl}$. Positive for oxidase, catalase, urease, $\alpha$ galactosidase, $\alpha$-glucosidase, $\alpha$-maltosidase, $\beta$-glucosidase, $\beta$-glucuronidase, $N$-acetyl-glucosaminidase, $\beta$-galactosidase, nitrate reduction, casein and Tween 20 hydrolysis, gelatin liquefaction, $\mathrm{NH}_{3}$ production and methyl red test. Negative for lysine decarboxylase, L-aspartic arylamidase, lipase, ornithine decarboxylase, arginine dihydrolase, Tween 80 and starch hydrolysis, melanin, indole and $\mathrm{H}_{2} \mathrm{~S}$ production, milk coagulation and peptonization. Utilizes glucose and sucrose as sole carbon sources, but not 


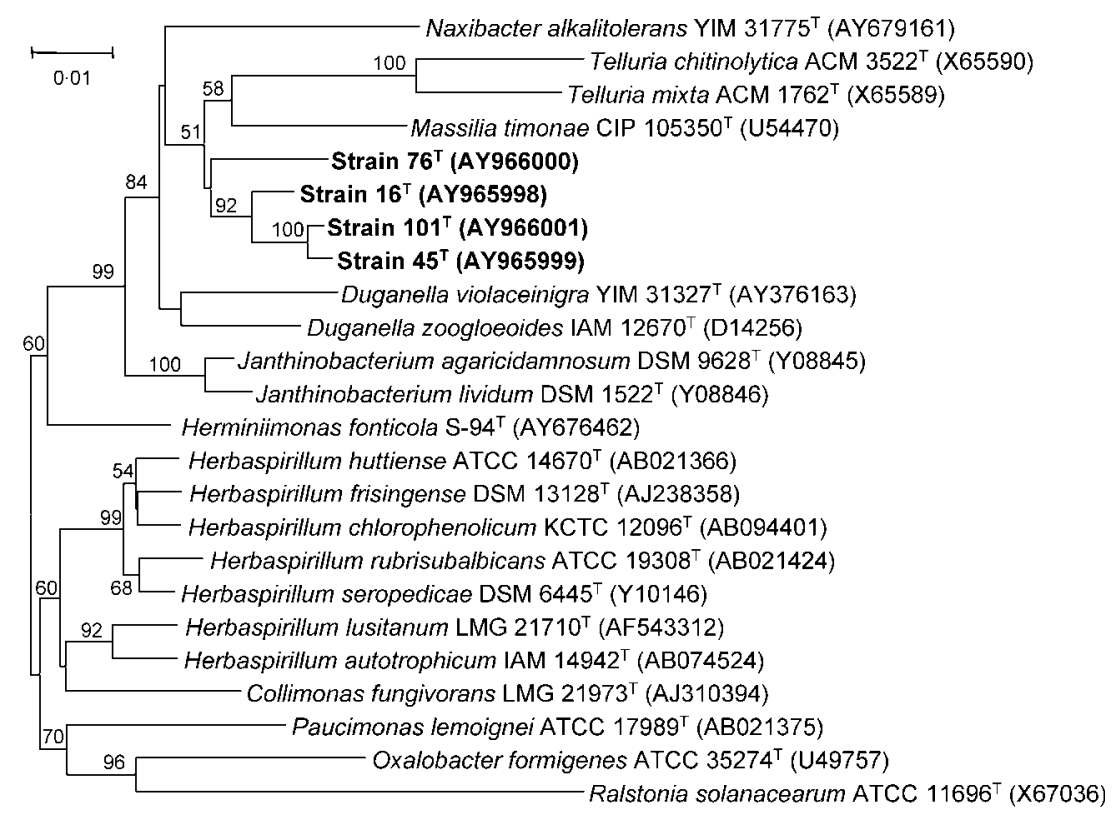

Fig. 2. Phylogenetic dendrogram obtained by neighbour-joining analysis based on $16 \mathrm{~S}$ rRNA gene sequences, showing the position of strains $16^{\top}, 45^{\top}, 76^{\top}$ and $101^{\top}$ among their phylogenetic neighbours. Numbers on branch nodes are bootstrap values (1000 resamplings). Sequence accession numbers are given in parentheses. The sequence of Ralstonia solanacearum ATCC $11696^{\top}$ was used as the root. Bar, 0.01 substitutions per nucleotide position. malonate, maltose, trehalose, rhamnose, inositol, adonitol, palatinose, cellobiose, sorbitol, D-arabitol, L-arabinose, mannitol, phenol red, galacturonate or L-arabitol. Major cellular fatty acids are $\mathrm{C}_{16: 1} \omega 7 c$ and $\mathrm{C}_{16: 0}$. Q-8 is the predominant respiratory quinone. The $\mathrm{G}+\mathrm{C}$ content of the genomic DNA is $65.9 \mathrm{~mol} \%$.

The type strain, strain $16^{\mathrm{T}}$ ( = CCTCC AB $204070^{\mathrm{T}}=\mathrm{KCTC}$ $12342^{\mathrm{T}}$ ), was isolated from heavy-metal-polluted farm soil, Nanjing, Jiangsu Province, China.

\section{Description of Massilia albidiflava sp. nov.}

Massilia albidiflava (al.bi.di.fla'va. L. adj. albidus whitish; L. adj. flavus yellow; N.L. fem. adj. albidiflava whitish yellow, referring to the colour of the colonies).

Colonies are $1.0-1.5 \mathrm{~mm}$ in diameter, circular, entire, convex, desiccated, opaque and pale white to yellow on nutrient agar plates. Cells are motile, non-spore-forming, short rods with peritrichous flagella, about $1 \cdot 8-2 \cdot 0 \mu \mathrm{m}$ in width and $3 \cdot 0-3 \cdot 5 \mu \mathrm{m}$ in length (Fig. 1b). Growth temperature and $\mathrm{pH}$ range for growth are $10-45^{\circ} \mathrm{C}$ and $\mathrm{pH} 6 \cdot 5-8 \cdot 5$, with optimum growth at $28-30{ }^{\circ} \mathrm{C}$ and $\mathrm{pH} 7 \cdot 0-7 \cdot 5$. Cannot tolerate $>1 \% \mathrm{NaCl}$. Positive for oxidase, catalase, $\alpha$ galactosidase, $\alpha$-glucosidase, $\alpha$-maltosidase, $\beta$-glucosidase, $\beta$-galactosidase, nitrate reduction, urease, $\mathrm{NH}_{3}$ production, gelatin liquefaction, starch, casein and Tween 20 hydrolysis. Negative for ornithine decarboxylase, arginine dihydrolase, indole, melanin and $\mathrm{H}_{2} \mathrm{~S}$ production, Voges-Proskauer and methyl red tests, milk coagulation and peptonization. Utilizes glucose and sucrose as sole carbon sources, but cannot utilize rhamnose, inositol, adonitol, palatinose, cellobiose, sorbitol, D-arabitol, L-arabinose, mannitol, phenol red, galacturonate or L-arabitol. Major cellular fatty acids are $C_{16: 1} \omega 7 c$ and $C_{16: 0}$. Q-8 is the predominant respiratory quinone. $\mathrm{G}+\mathrm{C}$ content of the genomic DNA is $65 \cdot 3 \mathrm{~mol} \%$.

The type strain, strain $45^{\mathrm{T}}\left(=\mathrm{CCTCC} \mathrm{AB} 204071^{\mathrm{T}}=\mathrm{KCTC}\right.$ $12343^{\mathrm{T}}$ ), was isolated from heavy-metal-polluted farm soil, Nanjing, Jiangsu Province, China.

\section{Description of Massilia plicata sp. nov.}

Massilia plicata (pli.ca'ta. L. part. adj. plicata folded, coiled, referring to the nature of the colonies).

Colonies are $2 \cdot 0-3 \cdot 0 \mathrm{~mm}$ in diameter, circular, entire, convex, viscous, opaque and yellow to pale brown on nutrient agar plates. Cells are motile, non-spore-forming, straight rods with one or more flagella, about $0 \cdot 6-0 \cdot 7 \mu \mathrm{m}$ in width and $2 \cdot 0-2 \cdot 5 \mu \mathrm{m}$ in length (Fig. 1c). Soluble pigment is produced on ISP 2 and some other tested media. Cells are $0 \cdot 6-0 \cdot 7 \mu \mathrm{m}$ in width and $1 \cdot 8-2 \cdot 2 \mu \mathrm{m}$ in length. Growth temperature and $\mathrm{pH}$ range for growth are $10-45^{\circ} \mathrm{C}$ and $\mathrm{pH} 6 \cdot 5-8 \cdot 5$, with optimum growth at $28-30{ }^{\circ} \mathrm{C}$ and $\mathrm{pH} 7 \cdot 0-7 \cdot 5$. Cannot tolerate $>1 \% \mathrm{NaCl}$. Positive for catalase, $\alpha$-galactosidase, $\alpha$-glucosidase, $\alpha$-maltosidase, $\beta$ glucosidase, $\beta$-galactosidase, L-aspartic arylamidase, lipase, urease, starch and casein, Tween 20 hydrolysis, gelatin liquefaction, Voges-Proskauer test, nitrate reduction and $\mathrm{NH}_{3}$ production. Negative for oxidase, lysine decarboxylase, $\beta$ glucuronidase, $N$-acetyl-glucosaminidase, ornithine decarboxylase, arginine dihydrolase, methyl red test, indole, melanin and $\mathrm{H}_{2} \mathrm{~S}$ production, milk coagulation and peptonization. Can utilize malonate, glucose and sucrose as sole carbon sources, but cannot utilize maltose, trehalose, rhamnose, inositol, adonitol, palatinose, cellobiose, sorbitol, D-arabitol, L-arabinose, mannitol, phenol red, galacturonate or L-arabitol. Major cellular fatty acids are $\mathrm{C}_{16: 1} \omega 7 c$ and $\mathrm{C}_{16: 0}$. Q-8 is the predominant respiratory quinone. $\mathrm{G}+\mathrm{C}$ content of the genomic DNA is $65 \cdot 1 \mathrm{~mol} \%$. 
The type strain, strain $76^{\mathrm{T}}\left(=\right.$ CCTCC AB $204072^{\mathrm{T}}=$ KCTC $12344^{\mathrm{T}}$ ), was isolated from heavy-metal-polluted farm soil, Nanjing, Jiangsu Province, China.

\section{Description of Massilia lutea sp. nov.}

Massilia lutea (lu.te'a. L. fem. adj. lutea golden yellow, referring to the colony colour).

Colonies are $2 \cdot 0-3 \cdot 0 \mathrm{~mm}$ in diameter, circular, entire, convex, viscous, opaque and yellow on nutrient agar plates. Cells are motile, non-spore-forming, short rods with peritrichous flagella, about $1 \cdot 8-2 \cdot 0 \mu \mathrm{m}$ in width and $3 \cdot 0-3 \cdot 5 \mu \mathrm{m}$ in length (Fig. 1d). Growth temperature and $\mathrm{pH}$ range for growth are $10-45^{\circ} \mathrm{C}$ and $\mathrm{pH} 6 \cdot 5-8 \cdot 5$, with optimum growth at $28-30{ }^{\circ} \mathrm{C}$ and $\mathrm{pH} 7 \cdot 0-7 \cdot 5$. Cannot tolerate $>1 \% \mathrm{NaCl}$. Positive for catalase, oxidase, $\alpha$-galactosidase, $\alpha$-glucosidase, $\alpha$-maltosidase, $\beta$-glucosidase, $\beta$-galactosidase, $\mathrm{NH}_{3}$ production and gelatin liquefaction. Negative for urease, ornithine decarboxylase, arginine dihydrolase, indole and $\mathrm{H}_{2} \mathrm{~S}$ production, nitrate reduction, Voges-Proskauer and methyl red tests, milk coagulation and peptonization. Can hydrolyse starch, casein and Tween 20, but not Tween 80 or cellulose. Utilizes glucose and sucrose as sole carbon sources, but not rhamnose, inositol, adonitol, palatinose, cellobiose, sorbitol, D-arabitol, L-arabinose, mannitol, phenol red, galacturonate or L-arabitol. Major cellular fatty acids are $\mathrm{C}_{16: 1} \omega 7 c$ and $\mathrm{C}_{16: 0}$. Q-8 is the predominant respiratory quinone. $\mathrm{G}+\mathrm{C}$ content of the genomic DNA is $63.3 \mathrm{~mol} \%$.

The type strain, strain $101^{\mathrm{T}}$ (=CCTCC AB $204073^{\mathrm{T}}=$ KCTC $12345^{\mathrm{T}}$ ), was isolated from heavy-metal-polluted farm soil, Nanjing, Jiangsu Province, China.

\section{Acknowledgements}

We are grateful to Dr Chantal Bizet for providing the type strain of $M$. timonae and also to Professor Dr Hans G. Trüper and Dr J. P. Euzéby for advice on the Latin construction of the species names. This work was supported by grants from the Chinese National Natural Science Foundation $(30200044,30570360)$ and Yunnan Science and Technology Commission (2005C0054M) and Jiangsu Natural Science Foundation (BK2005422).

\section{References}

De Ley, J., Cattoir, H. \& Reynaerts, A. (1970). The quantitative measurement of DNA hybridization from renaturation rates. Eur J Biochem 12, 133-142.

Felsenstein, J. (1981). Evolutionary trees from DNA sequences: a maximum likelihood approach. J Mol Evol 17, 368-376.

Felsenstein, J. (1985). Confidence limits on phylogenies: an approach using the bootstrap. Evolution 39, 783-791.

Felsenstein, J. (1993). PHYLIP - Phylogeny Inference Package, version 3.5c. Distributed by the author. Department of Genome Sciences, University of Washington, Seattle, USA.

Huß, V. A. R., Festl, H. \& Schleifer, K. H. (1983). Studies on the spectrophotometric determination of DNA hybridization from renaturation rates. Syst Appl Microbiol 4, 184-192.

Jahnke, K. D. (1992). BASIC computer program for evaluation of spectroscopic DNA renaturation data from Gilford System 2600 spectrophotometer on a PC/XT/AT type personal computer. J Microbiol Methods 15, 61-73.

Kelly, K. L. (1964). Inter-Society Color Council-National Bureau of Standards Color-Name Charts Illustrated with Centroid Colors. Washington, DC: US Government Printing Office.

Kimura, M. (1980). A simple method for estimating evolutionary rates of base substitutions through comparative studies of nucleotide sequences. J Mol Evol 16, 111-120.

Kimura, M. (1983). The Neutral Theory of Molecular Evolution. Cambridge: Cambridge University Press.

Kroppenstedt, R. M. (1982). Separation of bacterial menaquinones by HPLC using reverse phase (RP 18) and a silver loaded ion exchanger as stationary phases. J Liq Chromatogr 5, 2359-2387.

Kumar, S., Tamura, K., Jakobsen, I.-B. \& Nei, M. (2001). MEGA2: molecular evolutionary genetics analysis software. Bioinformatics 17, 1244-1245.

La Scola, B., Birtles, R. J., Mallet, M. N. \& Raoult, D. (1998). Massilia timonae gen. nov., sp. nov., isolated from blood of an immunocompromised patient with cerebellar lesions. J Clin Microbiol 36, 2847-2852. Leifson, E. (1960). Atlas of Bacterial Flagellation. London: Academic Press.

Li, W. J., Zhang, Y. Q., Park, D. J., Li, C. T., Xu, L. H., Kim, C. J. \& Jiang, C. L. (2004). Duganella violaceinigra sp. nov., a novel mesophilic bacterium isolated from forest soil. Int J Syst Evol Microbiol 54, 1811-1814.

Lindquist, D., Murrill, D., Burran, W. P., Winans, G., Janda, J. M. \& Probert, W. (2003). Characteristics of Massilia timonae and Massilia timonae-like isolates from human patients, with an emended description of the species. J Clin Microbiol 41, 192-196.

Marmur, J. (1961). A procedure for the isolation of deoxyribonucleic acid from microorganisms. J Mol Biol 3, 208-218.

Marmur, J. \& Doty, P. (1962). Determination of base composition of deoxyribonucleic acid from its denaturation temperature. J Mol Biol 5, 109-118.

Minnikin, D. E., O'Donnell, A. G., Goodfellow, M., Alderson, G., Athalye, M., Schaal, A. \& Parlett, J. H. (1984). An integrated procedure for the extraction of isoprenoid quinines and polar lipids. J Microbiol Methods 2, 233-241.

Saitou, N. \& Nei, M. (1987). The neighbor-joining method: a new method for reconstructing phylogenetic trees. Mol Biol Evol 4, 406-425.

Sasser, M. (1990). Identification of bacteria by gas chromatography of cellular fatty acids. USFCC Newsl 20, 16.

Shirling, E. B. \& Gottlieb, D. (1966). Methods for characterization of Streptomyces species. Int J Syst Bacteriol 16, 313-340.

Sintchenko, V., Jelfs, P., Sharma, A., Hicks, L., Gilbert, G. L. \& Waller, C. (2000). Massilia timonae: an unusual bacterium causing wound infection following surgery. Clin Microbiol Newsl 22, 149-151.

Thompson, J. D., Gibson, T. J., Plewniak, F., Jeanmougin, F. \& Higgins, D. G. (1997). The CLUSTAL_X windows interface: flexible strategies for multiple sequence alignment aided by quality analysis tools. Nucleic Acids Res 25, 4876-4882.

Wayne, L. G., Brenner, D. J., Colwell, R. R. \& 9 other authors (1987). Report of the ad hoc committee on reconciliation of approaches to bacterial systematics. Int J Syst Bacteriol 37, 463-464.

Xu, P., Li, W. J., Xu, L. H. \& Jiang, C. L. (2003). A microwave-based method for genomic DNA extraction from Actinomycetes. Microbiology 30, 82-84 (in Chinese).

Xu, P., Li, W.-J., Tang, S.-K., Zhang, Y.-Q., Chen, G.-Z., Chen, H.-H., Xu, L.-H. \& Jiang, C.-L. (2005). Naxibacter alkalitolerans gen. nov., sp. nov., a novel member of the family 'Oxalobacteraceae' isolated from China. Int J Syst Evol Microbiol 55, 1149-1153. 